\title{
Microstructure Analysis of Friction Stir Welding of Aluminum Alloy 6061 Coated with Copper Nanofilm
}

\author{
Sumanta Kumar Tripathy ${ }^{1, *}$, Sanjay Kumar,†, Azeez Mohammed Ali3,‡ \\ ${ }^{1}$ Associate Professor, Department of Physics, Gayatri Vidya Parishad College of Engineering (A), \\ Visakhapatnam, India \\ ${ }^{2}$ Associate Professor, Department of Mechanical Engineering, Gayatri Vidya Parishad College of Engineering (A), \\ Visakhapatnam, India \\ ${ }^{3}$ PG Scholar, Department of Mechanical Engineering, Gayatri Vidya Parishad College of Engineering (A), \\ Visakhapatnam, India
}

(Received 15 June 2021; revised manuscript received 15 August 2021; published online 20 August 2021)

\begin{abstract}
This work presents the effect of various input process parameters on grain size of aluminum alloy 6061 coated with copper nanofilm in friction stir welding. In this experiment, copper nanofilm is coated with thermal evaporation unit on the sides of aluminum alloy plates. Copper film is deposited inside the vacuum chamber at a pressure of $4 \times 10^{-4}$ Torr and a deposition rate of 4-6 $\AA$ per sec. The substrate temperature is maintained at 40 to $45^{\circ} \mathrm{C}$. The distance between the boat and the substrate is maintained at $10 \mathrm{~cm}$. Copper nanofilms with a thickness of 300,600 and $900 \mathrm{~nm}$ are fabricated on various aluminum alloy plates. Friction stir welding machine is used to perform the butt welding on aluminum alloy 6061 coated with copper nanofilm with different thickness. Welding speed, tool rotational speed and copper nanofilm coating thickness are considered as input process parameters, and grain size viz. grain area and grain perimeter as output parameters. Based on three input parameters, each at three levels, nine experiments are carried out using Taguchi L9 orthogonal array approach. Regression model is also developed to predict the grain size of the microstructure. Grain size of these samples is noted by using image analysis software with inverted metallurgical microscope at 200X magnification. It is observed that copper nanofilm coating has a significant impact on the grain area and grain perimeter. By increasing the nanofilm thickness from 600 to $1800 \mathrm{~nm}$, the mean grain area decreases by $20.83 \mu \mathrm{m}^{2}$ and simultaneously the mean grain perimeter decreases by $8.57 \mu \mathrm{m}$. Also, the copper nanofilm coating has the maximum effect on the grain size, followed by welding speed and tool rotational speed. By increasing the welding speed from 30 to $60 \mathrm{~mm} / \mathrm{min}$, the grain perimeter decreases by $6.47 \mu \mathrm{m}$, whereas the rotational speed has a mixed response.
\end{abstract}

Keywords: Copper nanofilm, Friction stir welding, Grain size, Rotational speed, Welding speed.

DOI: 10.21272/jnep.13(4).04037

PACS numbers: 68.37.Hk, 68.55. - a, 78.40. - q

\section{INTRODUCTION}

Reinforcement of nanoparticles in fusion welding is difficult and may not be possible due to its light weight which will float on the surface of weld bead. In friction stir welding, some literature is available to reinforce the nanoparticles during welding to improve the mechanical properties. Asl et al. [1] conducted friction stir welding on aluminum alloy AA6063 and magnesium alloy AZ31B by reinforcing $\mathrm{TiO}_{2}$ nanoparticles into the weld area by creating a surface groove to avoid dissipation of nanoparticles during welding. Azhiri et al. [2] carried out experiment with and without the addition of silica nanoparticles during friction stir welding. By X-ray diffraction and scanning electron microscopy analysis, the optimum welding condition is obtained. Hajideh et al. [3] investigated the impact of strengthening the acrylonitrile butadiene styrene and polypropylene joints by reinforcing copper particles into the welding region. Bahrami et al. [4] studied on friction stir welding of 7075 aluminum alloy to improve the mechanical properties and microstructure of weld joint by reinforcing SiC nanoparticles. Abdolahzadeh et al. [5] employed friction stir welding to join magnesium alloy plates and SiC particles were added at the weld area. Mirjavadi et al. [6] studied the effect of $\mathrm{TiO}_{2}$ nanoparticles addition on the microstructure of aluminum alloy AA5083 in friction stir welding. Jamalian et al. [7] studied the impact of $\mathrm{SiC}$ nanoparticles to know the effect on hardness and microstructure of the welding joints. Pasha et al. [8] studied the characteristics of AA6061 aluminum alloy welded butt joints reinforced by $\mathrm{SiC}$ which is welded by the friction stir welding process. Fakkir et al. [9] studied the optimization of the welding parameters of friction stir welding for aluminum alloys AA5083 and AA6061 under different parameters like rotational speed, feed and force on tensile strength, elongation and hardness. Chowdhury et al. [10] carried out experiments using process parameters such as tool tilt angle, welding and rotational speed in friction stir welding, and their individual effects on mechanical properties were examined. It was observed that microstructure analysis of friction stir welding of an aluminum alloy coated with copper nanofilm was not carried out. In this work, a new technique is adopted, and copper nanofilm of different thickness is coated by thermal evaporation unit on aluminum alloy plates to reinforce the nanoparticles in friction stir welding.

\footnotetext{
*tripathy@gvpce.ac.in

$\dagger$ sanjay_kumar74@gvpce.ac.in

† azeezmohammedali@gmail.com
} 


\section{EXPERIMENTAL PROCEDURE}

\subsection{Fabrication of Copper Nano Thin Film on Aluminum Alloy Plate}

Copper nano thin film is synthesized by thermal evaporation unit on the sides of aluminum alloy 6061 plates of $6 \mathrm{~mm}$ thickness. Before deposition of copper nanofilm, plates are cleaned with acetone and wrapped up with aluminum foil paper at unwanted areas and placed inside the vacuum chamber of thermal evaporation unit. Copper in the form of small chips is placed in a tungsten boat and connected between electrodes which are located inside the vacuum chamber. During the deposition process, the required thickness of the nanofilm coating is adjusted. Copper film is deposited at a vacuum chamber pressure of $4 \times 10^{-4}$ Torr and at a deposition rate of 4-6 $\mathrm{A}$ per sec at a substrate temperature of $40{ }^{\circ} \mathrm{C}$. The distance between the boat and the substrate is maintained at $10 \mathrm{~cm}$. Copper nanofilm coatings of a thickness of 300, 600 and $900 \mathrm{~nm}$ are fabricated on various aluminum alloy plates. During welding, when two plates are butt welded, the total copper nanofilm thickness will be 600, 1200 and $1800 \mathrm{~nm}$.

\subsection{Conducting the Welding Experiments}

A friction stir welding machine is used to perform the butt welding on aluminum alloy 6061 coated with copper nanofilm with different thickness. The welding plate is fixed by fixture which can be moved with the required speed in the horizontal direction during welding, the tool is in the vertical direction and can be rotated at the required speed. The rotating tool is moved towards the aluminum plates and thus heat is generated between the rotating tool and the aluminum plate.

Three input process parameters viz. welding speed, rotational speed and copper nanofilm thickness and their levels are shown in Table 1. Based on three input parameters, each at three levels, 9 experiments are conducted using Taguchi L9 orthogonal array approach as shown in Table 2.

Table 1 - Input parameters and their levels

\begin{tabular}{|c|c|c|c|}
\hline Input parameters & Level 1 & Level 2 & Level 3 \\
\hline $\begin{array}{c}\text { Welding speed, } S \\
\text { (mm/min) }\end{array}$ & 30 & 45 & 60 \\
\hline $\begin{array}{c}\text { Rotational speed, } N \\
(\text { rpm) }\end{array}$ & 1000 & 1300 & 1600 \\
\hline $\begin{array}{c}\text { Nanofilm thickness, } \\
T(\mathrm{~nm})\end{array}$ & 600 & 1200 & 1800 \\
\hline
\end{tabular}

\subsection{Measurement of Grain Size}

After completing the welding process, the weld samples are cut in the transverse direction. Emery papers of various grades - 120, 220, 320, 400, 1/0, 2/0, $3 / 0,4 / 0$ and $5 / 0$ - are used for polishing the welding area, and etchant $\mathrm{NaOH}$ solution $(15 \mathrm{~g} \mathrm{NaOH}+100 \mathrm{~g}$ distilled water) is applied on the polished surface to find the grain size of the microstructure. The grain size of these samples is noted by using image analysis software with inverted metallurgical microscope at $200 \mathrm{X}$ magnification. Fig. 3 and Fig. 4 show the microstructure of welding zone and microstructure after thresh- olding of welding zone, respectively, for sample 3 at $S=30 \mathrm{~mm} / \mathrm{min}, N=1600 \mathrm{rpm}$ and $T=1800 \mathrm{~nm}$.

After the following proper procedure like capturing image of microstructure and thresholding, the image analysis software provides the result of the grain area and grain perimeter as mentioned in Table 2.

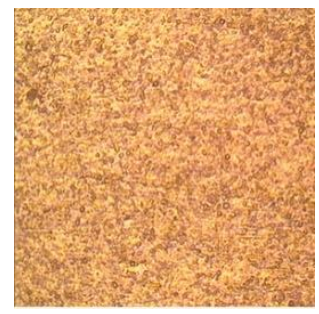

Fig. 3-Microstructure of welding zone

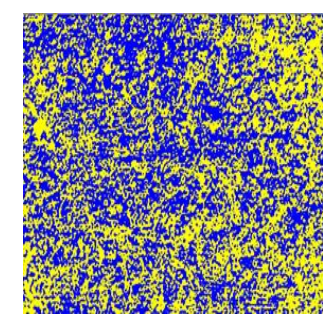

Fig. 4 - Microstructure after thresholding of welding zone
Table 2 - Experimental values of input and output parameters

\begin{tabular}{|c|c|c|c|c|c|}
\hline \multirow[b]{2}{*}{$\begin{array}{c}\text { Expt. } \\
\text { No. }\end{array}$} & \multicolumn{3}{|c|}{ Input parameters } & \multicolumn{2}{|c|}{ Output parameters } \\
\hline & $\begin{array}{c}S \\
(\mathrm{~mm} / \\
\mathrm{min}) \\
\end{array}$ & $\begin{array}{c}N \\
(\mathrm{rpm})\end{array}$ & $\begin{array}{c}T \\
(\mathrm{~nm})\end{array}$ & $\begin{array}{c}\text { Grain } \\
\text { area } \\
\left(\mu \mathrm{m}^{2}\right)\end{array}$ & $\begin{array}{c}\text { Grain } \\
\text { perimeter } \\
(\mu \mathrm{m})\end{array}$ \\
\hline 1 & 30 & 1000 & 600 & 89.89 & 44.5 \\
\hline 2 & 30 & 1300 & 1200 & 81.43 & 43.20 \\
\hline 3 & 30 & 1600 & 1800 & 71.95 & 37 \\
\hline 4 & 45 & 1000 & 1200 & 76.08 & 39.74 \\
\hline 5 & 45 & 1300 & 1800 & 56.54 & 34.2 \\
\hline 6 & 45 & 1600 & 600 & 90.77 & 47.2 \\
\hline 7 & 60 & 1000 & 1800 & 63.53 & 32.19 \\
\hline 8 & 60 & 1300 & 600 & 71.03 & 38.5 \\
\hline 9 & 60 & 1600 & 1200 & 58.66 & 33.9 \\
\hline
\end{tabular}

\section{ANALYSIS OF MEAN (ANOM) FOR GRAIN SIZE}

It is done to know the average effect of each input parameter on the output parameters.

Table 3 shows the analysis of mean for grain area which is calculated by taking the average of each parameter at that particular level. " $\delta$ " represents the difference between maximum and minimum values of each parameter. Its graphical representation is shown in Fig. 5.

It is observed that the nanofilm thickness has the greatest impact on the grain area, followed by the welding speed and rotational speed. By increasing the nanofilm thickness from 600 to $1800 \mathrm{~nm}$, the mean grain area decreases by $20.83 \mu \mathrm{m}^{2}$. Similarly, by increasing the welding speed from 30 to $60 \mathrm{~mm} / \mathrm{min}$, the grain area decreases by $16.75 \mu \mathrm{m}^{2}$, whereas rotational speed has mixed response.

Table 3 - Analysis of mean for grain area

\begin{tabular}{|c|c|c|c|}
\hline Level & $\begin{array}{c}\text { Welding } \\
\text { speed } \\
(\mathrm{mm} / \mathrm{min})\end{array}$ & $\begin{array}{c}\text { Rotational } \\
\text { speed } \\
(\mathrm{rpm})\end{array}$ & $\begin{array}{c}\text { Nanofilm } \\
\text { thickness } \\
(\mathrm{nm})\end{array}$ \\
\hline 1 & 80.37 & 76 & 83.61 \\
\hline 2 & 74.46 & 69.38 & 72.06 \\
\hline 3 & 63.63 & 73.07 & 62.78 \\
\hline Delta $(\delta)$ & 16.75 & 6.62 & 20.83 \\
\hline $\begin{array}{c}\text { Order of } \\
\text { effect }\end{array}$ & 2 & 3 & 1 \\
\hline
\end{tabular}


Table 4 shows the analysis of mean for grain perimeter and its graphical representation is shown in Fig. 6.

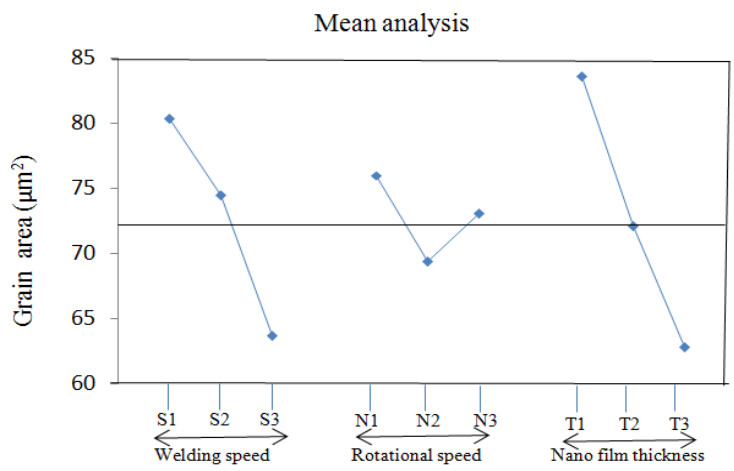

Fig. 5 - Mean analysis for grain area

Table 4 - Analysis of mean for grain perimeter

\begin{tabular}{|c|c|c|c|}
\hline Level & $\begin{array}{c}\text { Welding } \\
\text { speed } \\
(\mathrm{mm} / \mathrm{min})\end{array}$ & $\begin{array}{c}\text { Rotational } \\
\text { speed (rpm) }\end{array}$ & $\begin{array}{c}\text { Nanofilm } \\
\text { thickness } \\
(\mathrm{nm})\end{array}$ \\
\hline 1 & 41.70 & 39.33 & 43.40 \\
\hline 2 & 40.53 & 38.77 & 39.23 \\
\hline 3 & 35.23 & 39.37 & 34.83 \\
\hline Delta $(\delta)$ & 6.47 & 0.60 & 8.57 \\
\hline $\begin{array}{c}\text { Order of } \\
\text { effect }\end{array}$ & 2 & 3 & 1 \\
\hline
\end{tabular}

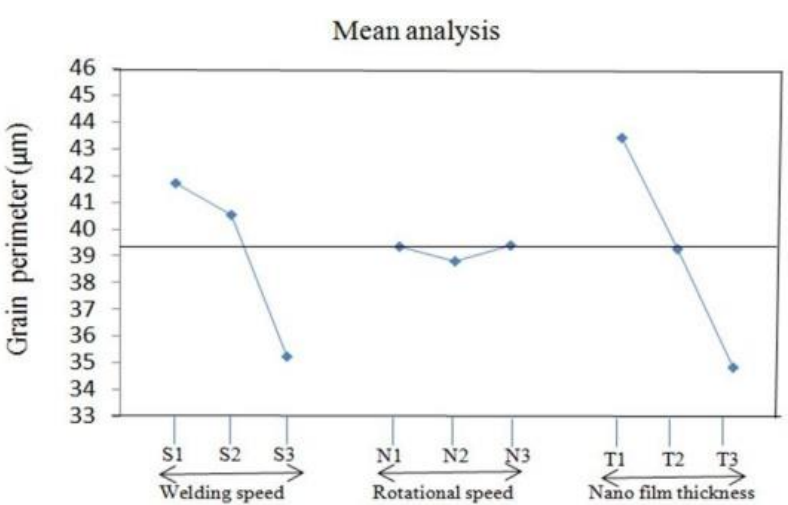

Fig. 6 - Mean analysis for grain perimeter

For the grain perimeter, it is also observed that the nanofilm thickness has the maximum impact, followed by the welding speed and rotational speed. By increasing the nanofilm thickness from 600 to $1800 \mathrm{~nm}$, the mean grain perimeter decreases by $8.57 \mu \mathrm{m}$. Also, by increasing the welding speed from 30 to $60 \mathrm{~mm} / \mathrm{min}$, the grain perimeter decreases by $6.47 \mu \mathrm{m}$, whereas the rotational speed has a mixed response.

\section{DEVELOPMENT OF A REGRESSION MODEL}

A regression model is developed using Minitab software from the values of input and output parameters from Table 2 for predicting the grain size.

The regression model for grain area:

$A=37.24+2.427 \times S+0.04111 \times N-0.03100 \times T-$ 0.01097. $\times S . \times S+0.000024 . \times N . \times N-0.000010 . \times$ T. $\times T-0.002159 \times S \times N+0.000674 \times S \times T$
The regression model for grain perimeter:

$P=-16.71+1.345 \times S+0.06665 \times N-0.01078 \times T-$ 0.009185. $\times S . \times S-0.000009 . \times N . \times N-0.000006$.

$\times T . \times T-0.000852 \times S \times N+0.000311 \times S \times T$

Table 5 - Predicted and percentage errors of grain size

\begin{tabular}{|c|l|l|l|l|l|l|}
\hline \multirow{2}{*}{ №. } & \multicolumn{2}{|c|}{ Grain area $\left(\mu \mathrm{m}^{2}\right)$} & \multicolumn{3}{c|}{ Grain perimeter $(\mu \mathrm{m})$} \\
\cline { 2 - 7 } & $\begin{array}{c}\text { Experi- } \\
\text { mental } \\
\text { values }\end{array}$ & $\begin{array}{c}\text { Predicted } \\
\text { values }\end{array}$ & $\begin{array}{c}\text { \%xperi- } \\
\text { Error }\end{array}$ & $\begin{array}{c}\text { Exedicted } \\
\text { mental } \\
\text { values }\end{array}$ & $\begin{array}{c}\text { Palues } \\
\text { Error }\end{array}$ \\
\hline 1 & 89.89 & 90.44 & 0.55 & 44.5 & 44.43 & -0.07 \\
\hline 2 & 81.43 & 82.64 & 1.21 & 43.20 & 43.6 & 0.4 \\
\hline 3 & 71.95 & 69.78 & -2.17 & 37 & 36.02 & -0.98 \\
\hline 4 & 76.08 & 76.99 & 0.91 & 39.74 & 40.2 & 0.46 \\
\hline 5 & 56.54 & 58.33 & 1.79 & 34.2 & 33.15 & -1.05 \\
\hline 6 & 90.77 & 92.06 & 1.29 & 47.2 & 47.24 & 0.04 \\
\hline 7 & 63.53 & 62.03 & -1.5 & 32.19 & 33.3 & 1.11 \\
\hline 8 & 71.03 & 70.18 & -0.85 & 38.5 & 38.47 & -0.03 \\
\hline 9 & 58.66 & 60.24 & 1.58 & 33.9 & 33.46 & -0.44 \\
\hline
\end{tabular}

In the regression model, interaction effect of $N \times T$ is negligible, so it is not specified in equation. The correlation coefficient for grain area and grain perimeter is obtained as 0.992 and 0.986 , respectively, that indicates that grain size can be predicted with very good accuracy. Table 5 shows the predicted values of grain size and percentage error which is within $2 \%$. To validate the regression model, more experiments are conducted at different values of input parameters other than those taken earlier as given in Table 6. It is found that percentage error is less than $5 \%$ for grain size.

Table 6 - Confirmation experiment input parameter values

\begin{tabular}{|c|c|c|c|}
\hline \multirow[b]{2}{*}{$\begin{array}{c}\text { Confirmation } \\
\text { Expt. No. }\end{array}$} & \multicolumn{3}{|c|}{ Input parameters } \\
\hline & $\begin{array}{c}\text { Welding } \\
\text { speed }\end{array}$ & $\begin{array}{c}\text { Rotational } \\
\text { speed }\end{array}$ & $\begin{array}{l}\text { Nanofilm } \\
\text { thickness }\end{array}$ \\
\hline CE1 & 37 & 1150 & 800 \\
\hline CE2 & 52 & 1450 & 500 \\
\hline
\end{tabular}

Table 7 - Validation of the regression model for grain size

\begin{tabular}{|c|c|c|c|c|c|c|}
\hline \multirow[b]{2}{*}{$\begin{array}{l}\text { CE } \\
\text { No. }\end{array}$} & \multicolumn{2}{|c|}{ Experimental values } & \multicolumn{2}{|c|}{ Predicted values } & \multicolumn{2}{|c|}{ \% Error } \\
\hline & $\begin{array}{c}\text { Grain } \\
\text { area }\end{array}$ & $\begin{array}{c}\text { Grain } \\
\text { perimeter }\end{array}$ & $\begin{array}{c}\text { Grain } \\
\text { area }\end{array}$ & $\begin{array}{c}\text { Grain } \\
\text { perimeter }\end{array}$ & $\begin{array}{c}\text { Grain } \\
\text { area }\end{array}$ & $\begin{array}{c}\text { Grain } \\
\text { perimeter }\end{array}$ \\
\hline CE1 & 67.21 & 35.23 & 68.23 & 34.56 & -1.52 & 1.90 \\
\hline CE2 & 57.23 & 43.56 & 55.16 & 45.67 & 3.62 & -4.84 \\
\hline
\end{tabular}

\section{CONCLUSIONS}

Friction stir welding on copper nanofilm coating of aluminum plates is performed at different welding speeds and rotational speeds using Taguchi L9 design of experiment. The nanofilm thickness has the maximum effect on the grain area followed by welding speed and rotational speed. By increasing the nanofilm thickness from 600 to $1800 \mathrm{~nm}$, the mean grain area decreases by $20.83 \mu \mathrm{m}^{2}$. The nanofilm thickness has the greatest effect on the grain perimeter followed by welding speed and rotational speed. By increasing the nanofilm thickness from 600 to $1800 \mathrm{~nm}$, the mean grain perimeter decreases by $8.57 \mu \mathrm{m}$. The regression model is developed which can predict the grain size within $5 \%$ accuracy. 


\section{ACKNOWLEDGEMENTS}

The authors of this paper are thankful to the management of the Gayatri Vidya Parishad College of En-

\section{REFERENCES}

1. N.S. Asl, S.E. Mirsalehi, K. Dehghani, J. Manuf. Proc. 38, 338 (2019).

2. R.B. Azhiri, R.M. Tekiyeh, E. Zeynali, M. Ahmadnia, F. Javidpour, Measurement 127, 198 (2018).

3. M.R. Hajideh, M. Farahani, N.M. Ramezani, J. Manuf. Proc. 32, 445 (2018).

4. M. Bahrami, N. Helmi, K. Dehghani, M.K.B. Givi, Mater. Sci. Eng. A 595, 173 (2014)

5. A. Abdolahzadeh, H. Omidvar, M.A. Safarkhanian, M. Bahrami, Int. J. Adv. Manuf. Technol. 75, 1189 (2014).

6. S.S. Mirjavadi, M. Alipour, S. Emamian, S. Kord, A.M.S. Hamouda, P.G. Koppad, R. Keshavamurthy, J. Alloy. Compd. 712, 795 (2017). gineering (Autonomous) for their support and provision of Laboratory facilities to carry out the research work.

\title{
Мікроструктурний аналіз зварювання фрикційним перемішуванням алюмініевого сплаву 6061, покритого мідною наноплівкою
}

\author{
Sumanta Kumar Tripathy ${ }^{1}$, Sanjay Kumar², Azeez Mohammed $\mathrm{Ali}^{3}$ \\ ${ }^{1}$ Associate Professor, Department of Physics, Gayatri Vidya Parishad College of Engineering (A), \\ Visakhapatnam, India \\ ${ }^{2}$ Associate Professor, Department of Mechanical Engineering, Gayatri Vidya Parishad College of Engineering (A), \\ Visakhapatnam, India \\ ${ }^{3}$ PG Scholar, Department of Mechanical Engineering, Gayatri Vidya Parishad College of Engineering (A), \\ Visakhapatnam, India
}

У роботі представлено вплив різних вхідних параметрів процесу на розмір зерен алюмініевого сплаву 6061, покритого мідною наноплівкою, при зварюванні фрикційним перемішуванням. У цьому експерименті мідна наноплівка формуеться методом термічного випаровування з боків пластин з алюмініевого сплаву. Мідна плівка осідае всередині вакуумної камери під тиском $4 \cdot 10^{-4}$ Торр і зі швидкістю осадження 4-6 ангстрем на секунду. Температуру підкладки підтримують від 40 до $45{ }^{\circ} \mathrm{C}$. Відстань між човном і підкладкою підтримуеться на рівні 10 см. Мідні наноплівкові покриття товщиною 300, 600 та 900 нм виготовляються на різних пластинах з алюмініевого сплаву. Зварювальний апарат 3 фрикційним зварюванням використовуеться для стикового зварювання на алюмініевому сплаві 6061, покритому мідною наноплівкою різної товщини. Площа зерна та периметр зерна слугують вихідними параметрами. На основі трьох вхідних параметрів, кожен на трьох рівнях, проводиться 9 експериментів із застосуванням ортогонального масиву Taguchi L. Модель регресії також розроблена для прогнозування розміру зерна мікроструктури. Розмір зерна цих зразків відмічаеться за допомогою програмного забезпечення для аналізу зображень з перевернутим металургійним мікроскопом при збільшенні 200X. Показано, що покриття мідною наноплівкою мае значний вплив на площу зерна та периметр зерна. Збільшуючи товщину плівки з 600 до 1800 нм, середня площа зерна зменшуеться на 20,83 мкм² і одночасно середній периметр зерна зменшуеться на 8,57 мкм. Крім того, мідне наноплівкове покриття має максимальний вплив на розмір зерна з наступною швидкістю зварювання та швидкістю обертання інструменту. Збільшуючи швидкість зварювання з 30 до 60 мм/хв, периметр зерна зменшуеться на 6,47 мкм, тоді як швидкість обертання має змішану реакцію.

Ключові слова: Наноплівка міді, Зварювання фрикційним перемішуванням, Розмір зерна, Швидкість обертання, Швидкість зварювання. 